\title{
Estimating the differences in critical thermal maximum and metabolic rate of Helicoverpa punctigera (Wallengren) (Lepidoptera: Noctuidae) across life stages
}

\author{
Samuel Bawa ${ }^{\text {Corresp., } 1,2}$, Peter Gregg ${ }^{3}$, Alice Del Soccoro ${ }^{3}$, Cara Miller $^{4}$, Nigel Andrew ${ }^{2}$ \\ 1 Asuansi Agric. Station, Box 520, Cape Coast, Ghana, Cape Coast, Central Region, Ghana \\ 2 Zoology,Insect Ecology Laboratory, University of New England, Armidale, NSW, Australia \\ 3 Agronomy and Soil Science, University of New England, Armidale, NSW, Australia \\ 4 Science and Technology, University of New England, Armidale, NSW, Australia \\ Corresponding Author: Samuel Bawa \\ Email address: ambiasin@yahoo.com
}

Temperature is a crucial driver of insect activity and physiological processes throughout their life-history, and heat stress may impact life stages (larvae, pupae and adult) in different ways. Using thermolimit respirometry, we assessed the critical thermal maxima ( $\mathrm{CT}_{\max }$ - temperature at which an organism loses neuromuscular control), $\mathrm{CO}_{2}$ emission rate $\left(\mathrm{VCO}_{2}\right.$ ) and Q10 (a measure of V́CO $\mathrm{CO}_{2}$ temperature sensitivity) of three different life stages of Helicoverpa punctigera (Wallengren) by increasing their temperature exposure from $25^{\circ} \mathrm{C}$ to $55^{\circ} \mathrm{C}$ at a rate of $0.25^{\circ} \mathrm{C} \mathrm{min}{ }^{-1}$. We found that the $\mathrm{CT}_{\max }$ of larvae $\left(49.1^{\circ} \mathrm{C} \pm 0.3^{\circ} \mathrm{C}\right)$ was higher than pupae $\left(47.4^{\circ} \mathrm{C} \pm 0.2^{\circ} \mathrm{C}\right)$ and adults $\left(46.9^{\circ} \mathrm{C} \pm 0.2^{\circ} \mathrm{C}\right)$. The mean massspecific $\mathrm{CO}_{2}$ emission rate $\left(\mathrm{ml} \mathrm{V́CO}_{2} \mathrm{~h}^{-1}\right)$ of larvae $\left(0.26 \pm 0.03 \mathrm{ml} \mathrm{V́CO}_{2} \mathrm{~h}^{-1}\right)$ was also higher

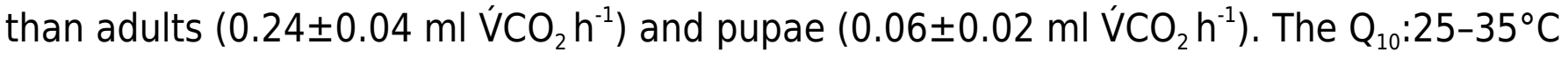
for adults $(2.01 \pm 0.22)$ was significantly higher compared to larvae $(1.40 \pm 0.06)$ and $\mathrm{Q}_{10}: 35-45^{\circ} \mathrm{C}$ for adults $(3.42 \pm 0.24)$ was significantly higher compared to larvae $(1.95 \pm 0.08)$ and pupae $(1.42 \pm 0.98)$ respectively. We have established the upper thermal tolerance of $H$. punctigera, which will lead to a better understanding of the thermal physiology of this species both in its native range, and as a pest species in agricultural systems. 
1 Estimating the differences in critical thermal maximum and metabolic rate of Helicoverpa

2 punctigera (Wallengren) (Lepidoptera: Noctuidae) across life stages

3 Samuel A. Bawa ${ }^{1,4 *}$,Peter C. Gregg ${ }^{2}$, Alice P.Del Socorro ${ }^{2}$, Cara Miller ${ }^{3}$, Nigel R. Andrew ${ }^{1}$

41 Insect Ecology Lab, Natural History Museum, School of Environmental and Rural Science, University of New England,

5 Armidale, NSW 2351, Australia.

62 Agronomy, School of Environmental and Rural Science, University of New England, Armidale, NSW 2351, Australia.

73 School of Science and Technology, University of New England, Armidale, NSW 2351, Australia

84 Asuansi Agric. Station, Box 520, Cape Coast, Ghana

10 Corresponding author: Samuel A. Bawa

11 Email address: abawa@myune.edu.au/ambiasin@yahoo.com

12 Postal address: Insect Ecology Lab, Natural History Museum, Building W77, University of New England, Armidale, 13 NSW 2351, Australia.

\section{Abstract}

16 Temperature is a crucial driver of insect activity and physiological processes throughout their life-

17 history, and heat stress may impact life stages (larvae, pupae and adult) in different ways. Using 18 thermolimit respirometry, we assessed the critical thermal maxima $\left(\mathrm{CT}_{\max }\right.$ - temperature at which

19 an organism loses neuromuscular control), $\mathrm{CO}_{2}$ emission rate $\left(\mathrm{V́CO}_{2}\right)$ and Q10 (a measure of $20 \mathrm{V́CO}_{2}$ temperature sensitivity) of three different life stages of Helicoverpa punctigera

21 (Wallengren) by increasing their temperature exposure from $25^{\circ} \mathrm{C}$ to $55^{\circ} \mathrm{C}$ at a rate of $0.25^{\circ} \mathrm{C} \mathrm{min}^{-1}$.

22 We found that the $\mathrm{CT}_{\max }$ of larvae $\left(49.1^{\circ} \mathrm{C} \pm 0.3^{\circ} \mathrm{C}\right)$ was higher than pupae $\left(47.4^{\circ} \mathrm{C} \pm 0.2^{\circ} \mathrm{C}\right)$ and 23 adults $\left(46.9^{\circ} \mathrm{C} \pm 0.2^{\circ} \mathrm{C}\right)$. The mean mass-specific $\mathrm{CO}_{2}$ emission rate $\left(\mathrm{ml} \mathrm{V} \mathrm{CO}_{2} \mathrm{~h}^{-1}\right)$ of larvae $24\left(0.26 \pm 0.03 \mathrm{ml} \mathrm{V} C O_{2} \mathrm{~h}^{-1}\right)$ was also higher than adults $\left(0.24 \pm 0.04 \mathrm{ml} \mathrm{V́}^{\prime} \mathrm{CO}_{2} \mathrm{~h}^{-1}\right)$ and pupae $25\left(0.06 \pm 0.02 \mathrm{ml} \mathrm{V́CO} \mathrm{h}^{-1}\right)$. The $\mathrm{Q}_{10}: 25-35^{\circ} \mathrm{C}$ for adults $(2.01 \pm 0.22)$ was significantly higher compared to larvae $(1.40 \pm 0.06)$ and $\mathrm{Q}_{10}: 35-45^{\circ} \mathrm{C}$ for adults $(3.42 \pm 0.24)$ was significantly higher compared to larvae $(1.95 \pm 0.08)$ and pupae $(1.42 \pm 0.98)$ respectively. We have established the upper thermal tolerance of $H$. punctigera, which will lead to a better understanding of the thermal physiology of this species both in its native range, and as a pest species in agricultural systems. 
30 Key words: Helicoverpa punctigera, life stage, critical thermal maxima, metabolic rate,

31 thermolomit respirometry

\section{Introduction}

33 Insects have a specific range of temperatures within which they can survive, grow and reproduce

34 (Andrew et al., 2011; Huang et al., 2015; DeVries et al., 2016), and have their distribution strongly

35 defined by a thermal envelope (Gullan \& Cranston, 2014; Li et al., 2019). Assessing the impact of

36 extreme temperature exposures on insect distribution is vital to understanding insect ecology and

37 the current and future effects of climate change (Andrew et al., 2011; Betini et al., 2013). Within

38 a rapidly changing climate, thermal limits are an essential part of assessing thermal physiology of

39 insects, as they are the critical endpoints that an organism can survive or loses muscular control

40 (Lighton \& Turner, 2004; Andrew et al., 2016), quantified in terms of critical thermal maximum

$41\left(\mathrm{CT}_{\max }\right)$ and critical thermal minimum $\left(\mathrm{CT}_{\min }\right)$ (Kingsolver et al., 2018).

42 Thermal limit measurements like $\mathrm{CT}_{\max }$ and $\mathrm{CT}_{\min }$ are commonly used to understand and predict

43 species distributions among populations (Shik et al., 2019) and responses to environmental

44 changes (Angilletta et al., 2003; Angilletta, 2009; Kingsolver et al., 2018). $\mathrm{CT}_{\max }$ is often aligned

45 to the distribution of species, as it is a biologically significant and ecologically relevant thermal

46 performance trait (Sunday et al., 2014; Shik et al., 2019). However, the $\mathrm{CT}_{\max }$ of most insect groups

47 is highly plastic, so can change depending on an organism's pre-exposure conditions, making it

48 difficult to forecast their response to a rapidly changing climate (Terblanche et al., 2005; Martínez

49 et al., 2016; Kellermann et al., 2017).

$50 \mathrm{CT}_{\max }$ has been shown to differ across life stages in some insects e.g. kelp fly (Paractora dreuxi),

51 Sirex wasp (Sirex noctilio) and mealworm (Tenebrio molitor) (Marais et al., 2009; Vorhees \& 
52 Bradley, 2012; Li et al., 2019), and can be influenced by body mass and surface area of the insect

53 (Lighton \& Turner, 2004). $\mathrm{CT}_{\max }$ values depend substantially on how they are measured (Lighton

$54 \&$ Turner, 2004; Shik et al., 2019); it is thus essential to determine a precise scale of temperature

55 exposure for insects (Terblanche et al., 2007). Temperature ramping rates can influence the $\mathrm{CT}_{\max }$

56 of an insect (Lighton \& Turner, 2004; Terblanche et al., 2007). A slow temperature ramp rate of

57 an organism leads to increased risk of heat shock, which is absent under the natural conditions

58 (Lutterschmidt and Hutchison, 1997). The other process that can occur during a slow ramp is short-

59 term physiological adjustments (e.g. induction of heat shock proteins) that protect cells from heat

60 damage and might increase $\mathrm{CT}_{\max }$ (Kingsolver, 2009; Shik et al., 2019). Fast temperature ramp

61 leads to delay in thermal equilibrium between the air and the insect's body. Because of this, under

62 a fast temperature ramp, the inner temperature of the insect will be lower than the recorded air

63 temperatures leading to an overestimation of their $\mathrm{CT}_{\max }$ (Lighton \& Turner, 2004; Andrew et al.,

64 2013; Agudelo-Cantero et al., 2019).

65 Intriguingly, only few studies have looked at thermal variation across different life stages (Le Lann

66 et al., 2011). The few studies focused on a single unit of fitness in one environment (Le Lann et

67 al., 2011). Thermal plasticity has been identified in many insect taxa e.g. ants Iridomyrmex

68 purpureus), Drosophila species and parasitic wasps (Aphidius rhopalosiphi) (Chown \&

69 Terblanche, 2006; Le Lann et al., 2011; Andrew et al., 2013; Shik et al., 2019), but not all

70 (Terblanche et al., 2010).

71 Insect herbivores that are found on the ground and plant surfaces in warmer and drier environments

72 are exposed to substantial microclimate variability including seasonal and daily temperature

73 variations at the soil and plant surface (Hodgson, 1991; Andrew et al., 2016). How organisms

74 respond to the variable microclimates depends on the thermal physiology e.g. $\mathrm{CT}_{\max }$ (Somero, 
75 2010; Shik et al., 2019). The physiology of insects can be modified by the microclimate they

76 experience (Andrew et al., 2013; Andrew et al., 2016). Predicting the future in changing climates

77 is made difficult by our limited understanding of the eco-physiological mechanisms and

78 evolutionary process underlying thermal phenotypic plasticity (Shik et al., 2019).

79 Helicoverpa punctigera is native to Australia and widely distributed across the continent (Gregg

80 et al., 2018). It is a notable pest on crops like cotton, oilseeds, legumes and vegetables (Gregg et

81 al., 2019). The adult can travel a long distance and can adapt locally to different environmental

82 conditions including inland Australia (Gregg et al., 2018, 2019). Female adult $H$. punctigera lay

83 eggs on leaves, flower buds and developing fruits of the host plant (Zalucki et al., 1986). The

84 neonate (newly hatched) usually eat soft leaves; as they mature, they move about other feeding

85 sites like flowers or flower buds, pods, fruits and seeds (Gregg et al., 2018). The last larval instar

86 burrows into the soil and pupates. Inland habitats are characterised by extreme climatic conditions

87 like very hot temperatures as high as $50^{\circ} \mathrm{C}$ during summer (Bureau of Meteorology, 2018). The

88 ability of this insect to survive the extreme summer temperatures in the inland depends on their

89 thermal tolerances and physiological sensitivities e.g., $\mathrm{CT}_{\max }$ and biochemical shifts that are

90 temperature-dependent (Gaitán-Espitia et al., 2014). Female adults of $H$. punctigera are

91 responsible for host selection and dispersal, whilst feeding activities of the larvae cause economic

92 loss to the host plants, and a complete reorganisation of the body occurs within the pupal stage,

93 understanding the metabolic rates among the different life stages are essential.

94 Energy is the crucial currency of life-history traits of animals including insects (Terblanche \&

95 Chown, 2007; Desforges et al., 2019). Metabolism combines organism's energy supply and

96 fitness-related activities (Shah et al., 2021). Measurement of metabolic rate is one way of

97 measuring the energy cost related with different life-functions like growth, development, 
98 movement among others (Shah et al., 2021). In insects, metabolic rates can influence not only

99 fitness in individuals but also geographic distributions and abundances (Shah et al., 2021).

100 Therefore, estimating the metabolic rates of organisms will assist in identifying the cost of living

101 and performance in a particular environment (Terblanche et al., 2005; Terblanche \& Chown,

102 2007), and can help predict geographic variations in response to global warming (Shah et al., 103 2021).

104 Metabolic rate can respond to changes in ambient temperature, activity and body mass; however, 105 age and ontogeny, sex, feeding status, season and time of day, among others, can also exert 106 substantial influence (Terblanche \& Chown, 2007; Harrison, 2009; Altermatt, 2010). For example, 107 in the Australian field cricket (Teleogryllus oceanicus) and thynnine wasp (Zaspilothynnus 108 nigripes), males have a higher metabolic rate than females (Kolluru et al., 2004; Tomlinson \& 109 Phillips, 2015). Specific dynamic action is the amount of energy expenditure above the basal 110 metabolic rate (RMR) due to the ingestion and digestion of food for use as energy or conversion 111 to a storage form (Secor, 2009). One major metabolic variable is the temporary rise in metabolic 112 rate following feeding status or swallowing food (Karasov \& Martinez del Rio, 2007; McCue et 113 al, 2012). This feeding status-associated rise in metabolic rate is a result of food breakdown and 114 processing in the gut of the organism (Karasov \& Martinez del Rio, 2007). High temperatures 115 generally produce high metabolic rate, however the total energy assigned for specific dynamic 116 actions is not fully dependent on temperature (McCue et al., 2016a; Wang et al., 2003).

117 The temperature sensitivity $\left(\mathrm{Q}_{10}\right)$, defined as the rate ratio of a given process taking place at

118 different temperatures, is used to measure the degree of temperature dependence of a given

119 biological process (Davidson et al., 2006; Mundim et al., 2020). $\mathrm{Q}_{10}$ is an important parameter in 120 predicting the effects of temperature on carbon dioxide release (Mundim et al., 2020). 
121 Previous studies on Helicoverpa species (eg. H. armigera and H. punctigera) focused on the effect

122 of temperature on development rate, survivorship and reproduction (Room, 1983; Qayyum \&

123 Zalucki, 1987; Mironidis et al., 2008; Zalucki et al., 2005; Mironidis, 2014) but not on thermal

124 physiology $\left(\mathrm{CT}_{\max }\right.$ and metabolic rate) of different life stages. For example, H. punctigera are

125 distinctive in terms of their life stage variation and habitat (Gregg et al., 2018, 2019), just as other

126 insects with stage-based niche changes. Across life stages, an individual will be exposed to a range

127 of temperatures (Agudelo-Cantero et al., 2019) with different opportunities to escape extreme

128 exposure. In the field, the larvae and adults of $H$. punctigera live on plant surfaces whiles the pupae

129 lives in the soil. Based on this life stage and habitat variations, their tolerance to extreme

130 temperatures may significantly vary among the different life stages. Our study is the first of $H$.

131 punctigera thermal physiology across three life-stages - larvae, pupae and adult.

132 We assessed the thermal physiology $\left(\mathrm{CT}_{\max }\right.$ and metabolic rate) of three different life stages - late

133 instar larvae, pupae, and adult - and sex of $H$. punctigera during temperature ramping using

134 thermolimit respirometry, which employs a flow-through respirometry, with $\mathrm{V}^{\mathrm{CO}} \mathrm{O}_{2}$ as a key

135 measure. The technique has an infrared activity detector to monitor moving activity (Lighton \&

136 Turner, 2004; Vorhees \& Bradley, 2012). One important advantage of this technique is that $\mathrm{CT}_{\max }$

137 can be identified directly from respiratory or activity data. In addition, it allows for $\mathrm{CT}_{\max }$ to be

138 determined without disturbing the organism (Vorhees \& Bradley, 2012). The technique, in

139 addition, allows for the measurement of $\mathrm{V}^{-O_{2}}$ when exposed to biologically relevant temperature 140 points.

141 The specific questions we asked are: 
142 (i) what are the differences in $\mathrm{V}^{-\mathrm{CO}_{2}}$ and $\mathrm{CT}_{\max }$ across different life stages of $\mathrm{H}$. punctigera

143 considering the different field conditions each stage experiences? We predict that, larvae and adult

144 of H. punctigera, which are exposed to the many microclimatic conditions on host plants surface,

145 would have a higher metabolic rate and $\mathrm{CT}_{\max }$ than pupae, because, the soil the pupae is burrowed

146 in is more thermally stable than the leaves.

147 (ii) what are the metabolic rates of the life stages at five different temperatures at $5^{\circ} \mathrm{C}$ bins: $25^{\circ} \mathrm{C}$,

$14830^{\circ} \mathrm{C}, 35^{\circ} \mathrm{C}, 40^{\circ} \mathrm{C}$ and $45^{\circ} \mathrm{C}$ ? Here, we predict that because exposure temperature has an overwhelming

149 effect on the metabolic rate of insects, the metabolic rate among the life stages would be lower at

$15025^{\circ} \mathrm{C}, 30^{\circ} \mathrm{C}$ and $35^{\circ} \mathrm{C}$ compared with $40^{\circ} \mathrm{C}$ and $45^{\circ} \mathrm{C}$.

151 (iii) does sex influence the metabolic rate and $\mathrm{CT}_{\max }$ of adult and pupae of $H$. punctigera? We

152 predict that because of the differences in activity (e.g., host selection and dispersal in the case of 153 adults) between male and female, sex would influence metabolic rate and $\mathrm{CT}_{\max }$ of $H$. punctigera 154 pupae and adult.

\section{Materials and methods}

\section{Insect Culture and Experimental Animals}

158 A laboratory insect culture was established in April 2018 from pupae provided by Tamworth 159 Agricultural Institute, New South Wales Department of Primary Industries. After emergence, the 160 adults were put into cylindrical framed mating cages containing 5\% sugar solution in dental wicks

161 held in $50 \mathrm{ml}$ plastic containers. We left female moths to mate and lay fertile eggs for 72 hours

162 following protocols outlined by Gregg et al. (2016). Eggs were collected by daily scrolling (by 163 way of folding) of the paper towel which acts as the mating cage wall, followed by cutting the 
164 towel containing the eggs into pieces measuring approximately $7 \mathrm{~cm} \times 21 \mathrm{~cm} \times 11 \mathrm{~cm}$. Eggs were

165 cleaned by brief immersion in $0.2 \%$ sodium hypochlorite solution for disease prevention, brushed

166 carefully for one to two minutes and then rinsed two times with distilled water onto filter paper

167 placed in a Büchner funnel. The cleaned eggs were put in plastic eggcups coated with artificial

168 diet and kept at $25^{\circ} \mathrm{C}$. Five days after hatching, the larvae were transferred into $35 \mathrm{ml}$ plastic cups

169 ventilated with small holes and containing 10-15 $\mathrm{ml}$ of soybean-based artificial diet (Greene et al.,

170 1976; Teakle, 1991). The insects were reared in the Agronomy insectary maintained at controlled

171 conditions of $70-75 \%$ relative humidity, $14 \mathrm{~h}$ : $10 \mathrm{~h}$ light: dark period and $25^{\circ} \mathrm{C}$, University of New

172 England, NSW, Australia. For a continuous supply of $H$. punctigera individuals at appropriate life-

173 stages, two cultures were maintained at different developmental stages. Before and after each

174 experiment, the larvae, pupae or adult moths used were weighed on an electronic balance (Mettler

175 Toledo XP 404S, Greifensee, Switzerland) with an adjusted accuracy of $0.1 \mathrm{mg}$. We used fifth

176 instar larvae in our experiment because they were available and relatively easy to manipulate

177 without damaging their cuticle. The average live body mass of the insects used pre-experiment

178 was $189.09 \pm 15.58 \mathrm{mg}$ for adults, $348.26 \pm 57.57 \mathrm{mg}$ for larvae and $332.38 \pm 18.39 \mathrm{mg}$ for pupae.

179 One-week-old pupae were sexed into male and female under a microscope using the genital scars

180 (Kirkpatrick, 1961) and used in pupal assays. Finally, virgin adults that were one to two days post-

181 emergence were used for the experiment: these adults were not fed. Because of the polyphagous

182 nature of the insect, larvae would always have a bite of a meal or would always have eaten in the

183 field, so all measures of metabolic rate include the specific dynamic action (roughly, the cost of

184 digestion) of the larvae. Larvae were fed with the same amount of food and quality ad-libatum,

185 until it was time to use for the experiment.

186 


\section{Experimental setup}

188 We used standard thermolimit respirometry protocols (Lighton \& Turner, 2004; Terblanche et al., 189 2007; Boardman \& Terblanche, 2015; Andrew et al., 2016; Ghaedi \& Andrew, 2016). In brief, 190 using a HiBlow HP40 air pump, room air was pushed into sodalime to remove $\mathrm{CO}_{2}$ and Drierite 191 to remove moisture. Air was set to flow at $180 \mathrm{ml} \mathrm{min}^{-1}$ using a mass flow controller (Sable MFC-2,

192 Sable Systems) and flow control valve (Side-Trak 840L; Sierra Instruments Inc., Monterey, CA, 193 USA) through Bev-a-line tubing to a 30ml glass cuvette. Carbon dioxide and water in the air that 194 was flowing before and after the glass cuvette was analysed by a two-channel calibrated infrared 195 Li-7000 analyser (Li-Cor, Lincoln, NE, USA). The scrubbed airstream flowed across the 196 experimental organism in the $30 \mathrm{ml}$ glass cuvette, which was held underwater in a water bath 197 (Grant, GP200-R4), programmed (resolution $\pm 0.1^{\circ} \mathrm{C}$ ) with LABWISE software. Cuvettes were 198 placed into two plastic bags to stop any water entering the cuvette. We warmed insects from $25^{\circ} \mathrm{C}$ 199 to $55^{\circ} \mathrm{C}$, at $0.25^{\circ} \mathrm{C} \mathrm{min}^{-1}$ (Andrew et al., 2016), over 120 minutes in the $30 \mathrm{ml}$ glass cuvette. The 200 outgoing air from the cuvette then enters the infrared $\mathrm{Li}$-cor analyser again: the $\mathrm{CO}_{2}$ concentration 201 difference of the air before and after it flowed through the cuvette, at one-second intervals is then 202 recorded. A type-T thermocouple attached to a data logger (PicoTech TC-08 data logger with 203 resolution $\pm 0.025^{\circ} \mathrm{C}$, accuracy $\pm 0.5^{\circ} \mathrm{C}$ ) was used to record the temperature in the glass cuvette.

204 The two data recordings (Licor and data logger) were combined using Microsoft excel, aligned 205 using the computer time stamp. An infrared activity detector (AD-1; Sable Systems, Las Vegas, 206 NV, USA) recorded the movement of the test insect (see trace in supplementary). 
209 Using Expedata (Sable Systems International, Las Vegas, NV, USA) version 1.9.2 analysis

210 software, data on $\mathrm{CO}_{2}$ emission rate was extracted and measured from $25^{\circ} \mathrm{C}$ to $55^{\circ} \mathrm{C}$ (Boardman

211 et al., 2015; Andrew et al., 2016). We drift-corrected our recordings to baseline recordings from

212 an empty $30 \mathrm{ml}$ glass cuvette made ten min before and after trial, and converted to $\mathrm{ml} \mathrm{CO}_{2} \mathrm{~h}^{-1}$

213 (Andrew et al., 2016; Ghaedi \& Andrew, 2016). We controlled chamber switching by recording

214 from the cuvette by manually adding/removing the insect from the same cuvette as the baseline.

215 For each replicate insect, $\mathrm{V} \mathrm{CO}_{2}(\mathrm{n}=10$ larvae, 10 pupae, 10 adults $)$ were extracted at these

216 temperature bins $\left(25,30,35^{\circ} \mathrm{C}, 40^{\circ} \mathrm{C}, 45^{\circ} \mathrm{C}\right.$ and $\mathrm{CT}_{\max } \pm 0.25^{\circ} \mathrm{C}$ ). The overall $\mathrm{V} \mathrm{CO}_{2}$ (in $\mathrm{ml} \mathrm{CO}_{2}$

$217 \mathrm{~h}^{-1}$ ) was calculated by extracting the area under the curve (integral of $\mathrm{CO}_{2} \mathrm{ml} \mathrm{h}^{-1}$ vs hours) in total

218 over the ramping period from $25^{\circ} \mathrm{C}$ to $\mathrm{CT}_{\max }$ by transforming ppm concentration of $\mathrm{CO}_{2}$ to $\mathrm{CO}_{2}$

219 fraction and then multiplied by the flow rate. This area was equal to the volume of $\mathrm{CO}_{2}$ produced

220 by each replicate insect in the $30 \mathrm{ml}$ glass cuvette (Stevens et al., 2010; Andrew et al., 2016). The

$221 \mathrm{V́CO}_{2}$ for each replicate insect at each temperature point was extracted and multiplied by 1,000 to

222 give $\mu \mathrm{CO}_{2} \mathrm{~h}^{-1}$ per insect per hour. $\mathrm{CT}_{\max }(\mathrm{n}=10$ larvae, 10 pupae, 10 adults $)$ was determined by

223 identifying the point at which the spiracular activity ceases i.e. the inflection point in the absolute

224 difference sum (ADS) residuals (Lighton \& Turner, 2004; Vorhees \& Bradley, 2012; Andrew et

225 al., 2016; Ghaedi \& Andrew 2016). Because of differences in activity among the life stages, to

226 standardise our analysis, we used $\mathrm{V}^{-\mathrm{CO}_{2}}$ data to determine $\mathrm{CT}_{\max }$ value not activity. Other studies

227 showed that $\mathrm{V} \mathrm{CO}_{2}$ and activities measurements produced similar estimates of $\mathrm{CT}_{\max }$ in insects

228 (Lighton \& Turner, 2004; Vorhees \& Bradley, 2012). Metabolic rates at $25^{\circ} \mathrm{C}, 35^{\circ} \mathrm{C}$ and $45^{\circ} \mathrm{C}$ for

$229 \mathrm{Q}_{10}$, were calculated as the average $\mathrm{V} \mathrm{CO}_{2}$ over the five-minute period at each temperature e.g. start

230 at $25^{\circ} \mathrm{C}$ and go to $26.25^{\circ} \mathrm{C}$. The inflection point for activity $\mathrm{ADS}$ residuals where motor activity 
231 ceases is the activity $\mathrm{CT}_{\max }$. Lighton \& Turner (2004) defined ADS as the cumulative sum of the

232 absolute difference between adjacent sampling points.

233

\section{Data analysis}

235 We considered our measures of $\mathrm{V́CO}_{2}$ as a proxy for metabolic rate (Terblanche et al., 2010).

236 Statistical analyses were carried out in $\operatorname{SAS}^{\circledR} 9.4$ software (SAS Institute Inc., 2013) using the

237 GLIMMIX procedure. $\mathrm{CT}_{\max }$ and total metabolic rate differences between the life stages were

238 determined using generalised linear models (GLM). Differences in metabolic rate for different

239 temperatures were assessed using generalised linear mixed models (GLMM) with individuals as

240 random factors to balance for the repeated measurement. A one-way analysis of variance

241 (ANOVA) was used to compare the overall $\mathrm{V}^{-C_{2}}$ and $\mathrm{CT}_{\max }$ among the life stages. The $\mathrm{Q}_{10}(25-$

$\left.24235^{\circ} \mathrm{C}\right)$ and $\mathrm{Q}_{10}\left(35-45^{\circ} \mathrm{C}\right)$ for the life stages were also recorded similar to the above described

243 procedure. Data were reported as means plus or minus standard error (mean $\pm \mathrm{SE}$ ). In all the

244 models $C T_{\max }$ and $\mathrm{V}^{-O_{2}}$ of individuals were the response variables with life stage as the

245 explanatory variables. Data was checked for normality and homogeneity of variance. The factors

246 in the model include life stage, sex and body mass as a covariate for metabolic rate. Because sex

247 was not significant for $\mathrm{CT}_{\max }$ and metabolic rate, data on sex for those parameters were combined

248 in the subsequent analysis. Mass was removed from the final model for $\mathrm{CT}_{\max }$ since it was not

249 significant. Where there were significant differences, post-hoc analysis was performed using least-

250 square means (LSmeans) and the differences compared, $\alpha=0.05$ (Tukey-Kramer Adjustment).

251 Mass was log-transformed before analysis. T-test was used to compare treatments under two

252 treatments. 


\section{Results}

255 Metabolic rate (overall $\mathrm{V́CO}_{2}\left(\mathrm{ml} \mathrm{h}^{-1}\right)$ across life stage of $\boldsymbol{H}$. punctigera

256 There was a significant effect of life stages on overall $\mathrm{V} C O_{2}(\mathrm{ANOVA}, \mathrm{DF}=2, \mathrm{~F}=31.52$, $257 \mathrm{p}<0.0001)$. Pupae $(\mathrm{n}=10)$ had an overall $\mathrm{V}^{\mathrm{CO}} \mathrm{O}_{2}$ of $41 \%$ lower than adults $(\mathrm{n}=10)$ and $50 \%$ lower 258 than larvae $(\mathrm{n}=10)(\mathrm{p}<0.0001$, and $\mathrm{p}<0.0001$, respectively; Figure 1$)$. The $\mathrm{V}^{\mathrm{CO}} \mathrm{O}_{2}$ of larvae was $9 \%$ 259 higher than adults, but not statistically significant $(\mathrm{p}=0.20$; Figure 1$)$.

\section{Upper thermal tolerance $\left(\mathrm{CT}_{\max }\right)$ across life stages of $\boldsymbol{H}$. punctigera}

262 There was a significant life stage effect on $\mathrm{CT}_{\max }$ (ANOVA, DF=2, $\left.\mathrm{F}=43, \mathrm{p}<0.0001\right)$. Adult $(\mathrm{n}=10)$ 263 and pupae $(n=10)$ had a similar $\mathrm{CT}_{\max }(\mathrm{p}=0.12$; Figure 2$)$. However, larvae $(\mathrm{n}=10)$ had a $\mathrm{CT}_{\max }$ on 264 average $2.2^{\circ} \mathrm{C}$ higher than adults and $1.8^{\circ} \mathrm{C}$ higher than pupae $(\mathrm{p}<0.0001 ; \mathrm{p}=<0.0001$, respectively;

265 Figure 2). Activity $\mathrm{CT}_{\max }$ and $\mathrm{CO}_{2} \mathrm{CT}_{\max }$ for adults were similar and not significant; unlike larvae, 266 which had significantly higher $\mathrm{CO}_{2} \mathrm{CT}_{\max }$ (Table 1).

\section{V́CO ${ }_{2}$ of $\boldsymbol{H}$. punctigera life stages at different temperature points}

269 Temperature effect on mean $\mathrm{V́CO}_{2}$ was high in adults and larvae compared to pupae (Table 2) at

270 the different temperature points. The mean $\mathrm{V}^{\mathrm{CO}} \mathrm{O}_{2}$ of pupae was significantly different from that of 271 adult and larvae at all temperature points except at $25^{\circ} \mathrm{C}$ (Table 2). The mean $\mathrm{V} \mathrm{CO}_{2}$ of each of the 272 life stages doubled at both $40^{\circ} \mathrm{C}$ and $45^{\circ} \mathrm{C}$ (Table 2) before $\mathrm{CT}_{\text {max. }}$ Although the mean $\mathrm{V}^{\circ} \mathrm{O}_{2}$

273 between adults and larvae was not significantly different at $40^{\circ} \mathrm{C}$, adults had a $0.01 \mu 1 \mathrm{~h}^{-1}$ higher 274 mean $\mathrm{V́CO}_{2}$ than larvae (Table 2). At equilibrium $\left(25^{\circ} \mathrm{C}\right)$ and $30^{\circ} \mathrm{C}-35^{\circ} \mathrm{C}$ larvae had $0.19 \mu 1 \mathrm{~h}^{-1}$, $2750.13 \mu 1 \mathrm{~h}^{-1}$ and $0.16 \mu 1 \mathrm{~h}^{-1}$ higher than adult (Table 2) respectively. The $\mathrm{Q}_{10} 25-35{ }^{\circ} \mathrm{C}$ values for 276 larvae and adults were lower compared to $\mathrm{Q}_{10} 35-45^{\circ} \mathrm{C}-28 \%$ lower for larvae $\left(\mathrm{Q}_{10}: 25-35^{\circ} \mathrm{C}\right.$ 
$2771.40 \pm 0.06$ to $\left.\mathrm{Q}_{10} 35-45{ }^{\circ} \mathrm{C} 1.95 \pm 0.14\right), 41 \%$ lower for adults $(2.01 \pm 0.22$ to $3.42 \pm 0.24)$ but $32 \%$

278 higher for pupae (1.74 0.21 to $1.42 \pm 0.98)$ (Figure 3). Among life stages the $\mathrm{Q}_{10}: 25-35{ }^{\circ} \mathrm{C}$ for

279 adults was significantly higher $(\mathrm{p}=0.04)$ compared with larvae, but not pupae $(\mathrm{p}=0.53$; Figure 3$)$.

280 The $\mathrm{Q}_{10}: 25-35^{\circ} \mathrm{C}$ was not significant between larvae and pupae $(\mathrm{p}=0.35$; Figure 3$)$. The $\mathrm{Q}_{10}: 35-$

$28145{ }^{\circ} \mathrm{C}$ values were not statistically different among larvae and pupae ( $\mathrm{p}=0.07$; Figure 3 ) but

282 significant among larvae and adults as well as pupae and adults $(\mathrm{p}=0.00, \mathrm{p}=0.00$; Figure 3$)$ 283 respectively.

285 The influence of sex on upper thermal limit $\left(\mathrm{CT}_{\max }\right)$ and metabolic rates $\mathrm{V́CO}_{2}\left(\mathrm{ml} \mathrm{h}^{-1}\right)$ of adult moth and pupae

287 There was no sex effect (ANOVA, $\mathrm{DF}=3, \mathrm{~F}=0.15, \mathrm{p}=0.92$; Figure 4 ) on the $\mathrm{CT}_{\max }$ of adults (males: 288 $46.92^{\circ} \mathrm{C} \pm 0.29^{\circ} \mathrm{C}$ and females: $46.72^{\circ} \mathrm{C} \pm 0.29^{\circ} \mathrm{C}$ ) and pupae (males: $47.47^{\circ} \mathrm{C} \pm 0.29^{\circ} \mathrm{C}$ and

289 females: $47.32^{\circ} \mathrm{C} \pm 0.29^{\circ} \mathrm{C}$ ). For metabolic rate assessments, there was no significant difference

290 between female and male adults as well as between female and male pupae $(t=-0.57, p=0.93$;

291 Figure 5) and ( $\mathrm{t}=1.38, \mathrm{p}=0.52$; Figure 5) respectively.

292

293

Discussion

294 Here, we measured the upper thermal tolerance limits $\left(\mathrm{CT}_{\max }\right)$ and metabolic rates at different 295 temperature exposures across three life stages larvae, pupae, and adults and between sexes of $H$. 296 punctigera using thermolimit respirometry. These life stages experience different temperatures

297 because of the different habitats they naturally occupy, enabling an ecologically relevant 298 investigation of their metabolic rates at different temperatures. We found that $\mathrm{CT}_{\max }$ differed 299 among the life stages of the insect with larvae exhibiting significantly higher $\mathrm{CT}_{\max }$ compared with 
300 pupae and adults (Figure 2). Similar to the findings presented here, studies by other authors have

301 shown that $\mathrm{CT}_{\max }$ differs among life stages of insects including Paractora dreuxi, Sirex noctilio

302 and Tenebrio molitor (Marais et al., 2009; Vorhees \& Bradley, 2012; Li et al., 2019). The higher

$303 \mathrm{CT}_{\max }$ of the larvae compared with adults however, contradicts the findings of Vorhees \& Bradley,

304 (2012) and Li et al., (2019) in T. molitor and S. noctilio respectively, where adults had a higher

$305 \mathrm{CT}_{\max }$ than larvae, although, the insects are of different taxa. The differences in the $\mathrm{CT}_{\max }$ between

306 the life stages suggest differences in upper thermal tolerance in this species with larvae having the

307 highest thermal tolerance to high temperature (Marais et al., 2009).

308 The $\mathrm{CT}_{\max }$ differences among the life stages could be caused by several different factors such as

309 interactions of the microclimatic conditions experienced by the life stages and the level to which

310 they compensate their physiology to avoid harsh or extreme temperatures (Vorhees \& Bradley,

311 2012). However, this would not be the case here, as all insects were kept at a constant $25^{\circ} \mathrm{C}$, so a

312 more evolutionarily relevant mechanism must be in train here. The results imply that, larvae, pupae

313 and adults have the ability in the wild to adapt and cope differently.

314 The significantly higher $\mathrm{CT}_{\max }$ exhibited by larvae is not surprising because larvae in their natural

315 environment are generally more exposed to extreme/hot temperatures, just above the soil surface

316 and while feeding on plants, and, less able to behaviourally adapt to extreme periods. Hence the

317 need to modify their physiological response to such extreme periods of heat conditions for survival

318 (Andrew et al., 2013a; Andrew et al., 2013b; Andrew et al., 2016). Even though the insects used

319 in the study were laboratory-reared, they were most likely to exhibit similar characteristics like

320 those in the field, because there is little genetic variability among H. punctigera population (Daly

321 et al., 1985). The limitation of our study is that; the low genetic diversity in the wild in the insect

322 does not imply that laboratory populations will not be adapted after many generations. We 
323 acknowledge that the climatic variability experienced in the wild could further influence in these

324 thermal tolerance traits, but is unlikely to affect the clear life-stage differences.

325 The decline in the upper thermal limit between larvae, pupae and adults in that order (Figure 2)

326 suggests that the insects upper thermal limit could be influenced by ontogeny as observed in

327 Drosophila melanogaster (Bowler \& Terblanche, 2008), although we did not test for age effects

328 in a single life stage. This upper thermal limit decline across the life stages however, does not

329 always follow a logical order as in some insect's e.g. Drosophila buzzatii; heat tolerance was high

330 in pupae followed by eggs and larvae (as cited in Vorhees \& Bradley, 2012). Therefore, caution

331 must be made against the generalisation concerning the effects of ontogeny on heat resistance

332 (Vorhees \& Bradley, 2012), although we should expect ontogenetic variation (Bowler \&

333 Terblanche, 2008). One would have expected in part, no significant difference in the $\mathrm{CT}_{\max }$

334 between larvae and adults because of the several factors like the microclimate conditions they

335 experienced and the extent to which they can use their physiology to avoid the extreme

336 temperatures. The lower $\mathrm{CT}_{\max }$ of the adults compared with the larvae may be because the adults

337 have a higher ability to avoid extreme temperatures by flying away from areas of extreme

338 temperatures compared to larvae. The results suggest that there are ecological reasons for different

339 thermal preferences: larvae are more sedentary so it is harder for them to move away from hotter

340 temperatures they may be exposed to; adults are more mobile, so can move to preferred

341 temperatures refuges in the evening so have a lower thermal threshold. Because of the ectothermic

342 and regional heterothermic nature of insects, high temperatures could speed up growth and

343 development of insects (Andrew et al., 2011; DeVries et al., 2016). The higher $\mathrm{CT}_{\max }$ of the larvae

344 could assist them to grow faster in warmer conditions like summer if food, and most importantly

345 water, are not limiting factors. 
346 The $\mathrm{CT}_{\max }$ exhibited by the life stages is significantly greater than the highest recorded maximum

347 daily mean ambient temperature in Tamworth region where the population originated from

$348\left(40.9^{\circ} \mathrm{C}\right)($ NicheMapR). However, the microclimatic conditions that $H$. punctigera could be

349 exposed to may be much higher than this, particularly during the middle of the day (Andrew et al.,

350 2013), and can put the insects under physiological stress that can change their interactions under

351 changing climate. The higher $\mathrm{CT}_{\max }$ exhibited by the insect could be the reason for which it is able

352 to occupy a wide range of climatic conditions including inland of Australia, and spread in all states

353 of Australia (Gregg et al., 2018, 2019).

354 Our results show that upper thermal limits were not significantly different between males and

355 females. The similar thermal limits demonstrated by males and females indicates that sex has

356 minimal influence on $\mathrm{CT}_{\max }$ (Figure 4), similar to the findings in bumble bees (Bombus terrestris)

357 (Oyen et al., 2016); suggesting that $H$. punctigera sex ratios will not change with adult exposure

358 to climatic extremes.

359 Insects as other animals require energy to forage, survive, grow and reproduce (Terblanche et al.,

360 2004; White et al., 2019). The processes that cause variation in metabolic rate apart from ambient

361 temperature, body mass is also an important factor that contributes to metabolic rate of insects

362 (White et al., 2019). Insects show a range of thermoregulatory capacities: ectothermic, regional

363 heterothermic, poikilothermic and endothermic (Heinrich, 1993; Gullan \& Cranston, 2014) their

364 activity and physiological processes are primarily influenced by ambient temperature (Nguyen et

365 al., 2014). Our results revealed $\mathrm{V}^{\mathrm{C}} \mathrm{CO}_{2}$ varied among the life stages at the different temperature

366 points. The differences in the mean $\mathrm{V} \mathrm{CO}_{2}$ among the life stages suggests that the metabolic

367 demands of the life stages differ. Several factors may account for the differences in the metabolic 
368 rates among the life stages; including ontogeny, upper thermal tolerance, activity, body mass and

369 feeding (Terblanche et al., 2005).

370 Fat body tissues play crucial roles in the life of insects, as they are involved in multiple metabolic

371 functions like energy storage and utilisation in reply to the energy call or request of the insect

372 (Arrese \& Soulages, 2010). Muscle tissue usually has a higher metabolic rate than fat body tissue.

373 Muscle tissues are active and burns calories even at rest unlike fat body for storing excess energy.

374 The significantly higher $\mathrm{V}^{\mathrm{CO}} \mathrm{O}_{2}$ of larvae and adult compared with pupae could be due to low 375 amount of fat body tissues in the larvae and high muscle tissues in the case of adult. Another reason

376 for the high metabolic rate may be due to the high activities of larvae and adult compared with

377 pupae, similar to that reported by DeVries et al. (2013) for the bed bug, Cimex lectularius. Size

378 also affects the metabolic rate of an organism (Terblanche et al., 2004; Quinlan et al., 2006;

379 DeVries et al., 2013), and was similar in our case, as size was significant (Figure 8 in

380 supplementary material). Pupae, which has a higher $\mathrm{CT}_{\max }$ than adults, had a comparative lower

$381 \mathrm{V́CO}_{2}$. The lower $\mathrm{V}^{\mathrm{CO}} \mathrm{O}_{2}$ may be an indication of lower stress at the higher temperatures and or

382 maybe due to more fat tissues in pupae. It is plausible that it may be an adaption strategy for

383 survival to dry conditions (Terblanche et al., 2004; Quinlan et al., 2006). The high amount of fat

384 tissues in the pupae because of lipid reserves needed to provide energy during the extended non-

385 feeding periods could be the reason for the low metabolism (Arrese \& Soulages, 2010). Because

386 pupae do not have a source of free water underground, they must conserve water by reducing

387 respiration (Table 3 in supplementary material) (Harrison, 2009).

388 As the effect of temperature on metabolic rates of insects is widely reported (Terblanche et al.,

389 2004, 2007; Hill et al., 2016), only a few studies looked at that at different temperature points for

390 different life stages for $H$. punctigera. Our results on metabolic rate between life stages considering 
391 the different temperatures (Table 2) and $\mathrm{Q}_{10}$ (Figure 3) indicates that there was a correlation

392 between temperature rise and $\mathrm{V} \mathrm{CO}_{2}$ release on the life stages during the thermolimit respiratory

393 (Table 2). The $\mathrm{Q}_{10}$ values for all the life stages except pupae almost doubled from $\mathrm{Q}_{10}: 25-35^{\circ} \mathrm{C}$

394 to $\mathrm{Q}_{10}: 35-45^{\circ} \mathrm{C}$, with adults having the highest thermal sensitivity. This increase in metabolic

395 rate as temperature increases is consistent with other studies (Terblanche et al., 2005; Terblanche

396 \& Chown 2007; Andrew et al., 2016). However, the negative effects associated with increasing

397 temperatures on metabolic efficiency could be reduced on adults, as they are able to compensate

398 for short-term extreme microclimate temperatures by flying away. Although, increase in

399 temperatures result in high metabolic rate, the total energy assigned for certain actions, as specific

400 dynamic actions are not dependent on temperature (McCue et al., 2016a; Wang et al., 2003). It is

401 possible that as insects enlarge their geographic radius or scale, they will face abiotic and biotic 402 stress.

403 For better comparison among life stages, we measured $\mathrm{V́CO}_{2}$ at $\mathrm{CT}_{\max }$, and in all cases, $\mathrm{V} \mathrm{CO}_{2}$ 404 among life stages was higher. Even though the $\mathrm{VCO}_{2}$ at $\mathrm{CT}_{\max }$ increased in all the life stages, adults $405 \mathrm{V́CO}_{2}$ were higher than larvae and pupae. Harrison (2009) reported that tracheated insects have the 406 ability to carry or move gases by opening their spiracles. Short periods of spiracles closure follow 407 a continuous carbon dioxide exchange (Harrison, 2009). The higher metabolic rates due to higher 408 stress levels may be due to a decrease between spiracle opening and closing. Therefore, the higher $409 \mathrm{V́CO}_{2}$ of adults at $\mathrm{CT}_{\max }$ may be due to their high activity rate and a decrease between its spiracle 410 opening and closing compared to larvae and pupae (Harrison, 2009; Boardman et al., 2015). The

411 lower metabolic rate of pupae at $\mathrm{CT}_{\max }$ compared to larvae and adults could not be explained 412 beyond a physiological adaption strategy to reduce physiological cost by reducing respiration and 
413 conserve water at this stage (Harrison, 2009), similar to what Merkey et al. (2011) reported in

414 Drosophila melanogaster pupae.

415 The lower $\mathrm{V́CO}_{2}$ of adults compared to larvae at $25^{\circ} \mathrm{C}$ could suggest that adults have a lower

416 resting metabolic rate than larvae at that point. The higher resting metabolic rate of larvae could

417 be the result of modification of the energy allocation between competing functions such as

418 maintenance for continuous development. Additionally, the lower $\mathrm{V}^{\mathrm{CO}} \mathrm{O}_{2}$ of adults may be as result

419 of the occurrence of discontinuous gas exchange in the adults at $25^{\circ} \mathrm{C}$. Discontinuous gas exchange

420 is associated with low metabolic rates. In contrast, age, as proven to affect metabolic rates in some

421 insects like Glossina pallidipes (Terblanche et al., 2004) did not apply in our case, as larvae had a

422 lower $\mathrm{V} \mathrm{CO}_{2}$. The high $\mathrm{V} \mathrm{CO}_{2}$ produced by the larvae could imply a high-energy utilisation

423 (Terblanche et al., 2004) for development. This high-energy utilisation can provide a deep

424 understanding into the life histories of the life stage across a variety of environments. Therefore,

425 this high-energy utilisation may translate to an increase in food consumption and more 426 considerable plant damage (Deutsch et al., 2018). The metabolic rate of pupae and adults was not

427 influenced by sex, suggesting that the cost of living of the dispersing adults and pupae of both

428 sexes are similar. Similar work by Terblanche et al. (2004) found out that metabolic rate did not 429 differ between males and females of Glossina pallidipes and G. morsitans.

430

431 Conclusion

432 The present study provides vital information on how the different life stages of $H$. punctigera will

433 physiologically perform in a changing thermal environment. It also provides data for predictions

434 about metabolic rates of $H$. punctigera among life stages. The study revealed that $\mathrm{CT}_{\max }$ of larvae 435 was significantly higher than those of pupae and adults, and the metabolic rate of pupae was 
436 significantly different from those of larvae and adults. Also, sex did not influence $\mathrm{CT}_{\max }$ and

437 metabolic rate. The results suggest that the performance and survival of the different life stages of 438 H. punctigera could differ. This indicates that life-stage needs to be taken into account when 439 assessing responses to a rapidly changing change, as ontogeny influences vulnerability and 440 exposure. This finding can be used to predict the potential spread of the insect to other new 441 environments and can indirectly help in management planning.

\section{Acknowledgements}

Sarah Hill assisted with the setup, calibration, maintenance and protocols of the thermolimit 445 respirometry system. Zac Hemmings assisted in the data extraction, analysis and initial interpretations of the raw-data outputs. We thank Bianca Boss-Bishop, Sarah Hill, James O'Hanlon, Zac Hemmings, Alva Rebecka Curtsdotter and Behnaz Ghaedi for their comments on earlier versions of the manuscript. Also NSW DPI for providing the insects for the culture.

Declarations of interest: Nigel R. Andrew is an Academic editor of PeerJ

451

452

453

454

455

456 data collection and analysis, decision to publish, or preparation of the manuscript.

\section{Funding}

University of New England (UNE) provided funds as scholarship to Samuel Abukari Bawa as well as for equipment and consumables used in the study. The funders had no role in the study design,

\section{Author Contributions}


461 All authors conceived and designed the experiment. The first author (Samuel Abukari Bawa)

462 performed the experiment. The data was analysed by Samuel Abukari Bawa and Cara Miller.

463 Samuel Abukari Bawa wrote the paper, prepared figures and tables. Nigel R. Andrew, Peter C.

464 Gregg and Alice P.Del Socorro reviewed the drafts of the paper and contributed to writing the 465 paper.

466 References

467 Altermatt, F. 2010. Climatic warming increases voltinism in European butterflies and moths. 468 Proceedings of the Royal Society of London B: Biological Sciences, 277(1685), 1281-1287.

469 Arrese, E. L., \& Soulages, J. L. 2010. Insect fat body: energy, metabolism, and regulation. Annual 470 review of entomology, 55, 207-225

471 Andrew, N. R., Ghaedi, B., \& Groenewald, B. 2016. The role of nest surface temperatures and 472 the brain in influencing ant metabolic rates. Journal of thermal biology, 60, 132-139.

473 Andrew, N. R., Hart, R. A., Jung, M.-P., Hemmings, Z., \& Terblanche, J. S. 2013. Can 474 temperate insects take the heat? A case study of the physiological and behavioural responses in a 475 common ant, Iridomyrmex purpureus (Formicidae), with potential climate change. Journal of 476 Insect Physiology, 59(9), 870-880.

477 Andrew, N.R. 2013. Population dynamics of insects: impacts of a changing climate. The Balance 478 of Nature and Human Impact (ed. K. Rohde), pp. 311-323. Cambridge University Press.

479 Andrew, N. R., \& Terblanche, J. S. 2013. The response of insects to climate change. Climate of 480 Change: Living in a Warmer World. Auckland: David Bateman Ltd, 38-50. 
481 Andrew, N. R., Hart, R. A., \& Terblanche, J. S. 2011. Limited plasticity of low temperature 482 tolerance in an Australian cantharid beetle Chauliognathus lugubris. Physiological Entomology, 483 36(4), 385-391.

484 Andrew, N. R., \& Hill, S. J. 2017. Effect of Climate Change on Insect Pest Management. 485 Environmental Pest Management: Challenges for Agronomists, Ecologists, Economists and 486 Policymakers, 197.

487 Angilletta Jr, M. J., \& Angilletta, M. J. 2009. Thermal adaptation: a theoretical and empirical 488 synthesis: Oxford University Press.

489 Angilletta, J., Michael J, \& Dunham, A. E. 2003. The temperature-size rule in ectotherms: 490 simple evolutionary explanations may not be general. The American Naturalist, 162(3), 332-342.

491 Angilletta Jr, M. J., Wilson, R. S., Navas, C. A., \& James, R. S. 2003. Tradeoffs and the 492 evolution of thermal reaction norms. Trends in Ecology \& Evolution, 18(5), 234-240.

493 Agudelo-Cantero, G. A., \& Navas, C. A. 2019. Interactive effects of experimental heating rates, 494 ontogeny and body mass on the upper thermal limits of anuran larvae. Journal of thermal biology, 495 82, 43-51.

Arnold, P. A., Nicotra, A. B., \& Kruuk, L. E. 2019. Sparse evidence for selection on phenotypic 497 plasticity in response to temperature. Philosophical Transactions of the Royal Society B, 498 374(1768), 20180185.

499 Bale, J. 2010. Implications of cold-tolerance for pest management. Low temperature biology of 500 insects, 342-373. 
501 Bale, J. S., Masters, G. J., Hodkinson, I. D., Awmack, C., Bezemer, T. M., Brown, V. K.,

502 Farrar, J. 2002. Herbivory in global climate change research: direct effects of rising temperature 503 on insect herbivores. Global Change Biology, 8(1), 1-16.

504 Betini, G. S., Griswold, C. K., \& Norris, D. R. 2013. Carry-over effects, sequential density 505 dependence and the dynamics of populations in a seasonal environment. Proceedings of the Royal 506 Society of London B: Biological Sciences, 280(1759), 20130110.

507 Betz A. \& Andrew N. R. 2020. Influence of non-lethal doses of natural insecticides Spinetoram 508 and Azadirachtin on Helicoverpa punctigera (native budworm, Lepidoptera: Noctuidae) under 509 laboratory conditions. Front. Inv. Physiol.

510 Boardman, L., \& Terblanche, J. S. 2015. Oxygen safety margins set thermal limits in an insect 511 model system. Journal of Experimental Biology, 218(11), 1677-1685.

512 Bowler, K. and Terblanche, J. S. 2008. Insect thermotolerance: what is the role of ontogeny, 513 ageing and senescence? Biol. Rev. 83, 339-355.

514 Chown, S.L., Terblanche, J.S. 2006. Physiological diversity in insects: ecological and 515 evolutionary contexts. Advances in insect physiology 33, 50-152.

516 Daly, J. C., \& Gregg, P. 1985. Genetic variation in Heliothis in Australia: species identification 517 and gene flow in the Two-pest species $H$. armigera (Hübner) and H. punctigera Wallengren 518 (Lepidoptera: Noctuidae). Bulletin of Entomological Research, 75(1), 169-184.

519 Duncan, F. D., Krasnov, B., \& McMaster, M. 2002. Novel case of a tenebrionid beetle using 520 discontinuous gas exchange cycle when dehydrated. Physiological Entomology, 27(1), 79-83. 
521 Davidson, E. A., Janssens, I. A., \& Luo, Y. (2006). On the variability of respiration in terrestrial

522 ecosystems: moving beyond Q10. Global Change Biology, 12(2), 154-164.

523 Dawson, T. P., Jackson, S. T., House, J. I., Prentice, I. C., \& Mace, G. M. 2011. Beyond 524 predictions: biodiversity conservation in a changing climate. Science, 332(6025), 53-58.

525 Deutsch, C. A., Tewksbury, J. J., Tigchelaar, M., Battisti, D. S., Merrill, S. C., Huey, R. B., \&

526 Naylor, R. L. 2018. Increase in crop losses to insect pests in a warming climate. Science, 527 361(6405), 916-919.

528 DeVries, Z. C., Kells, S. A., \& Appel, A. G. 2013. Standard metabolic rate of the bed bug, Cimex 529 lectularius: effects of temperature, mass, and life stage. Journal of Insect Physiology, 59(11), $530 \quad 1133-1139$.

531 DeVries, Z. C., Kells, S. A., \& Appel, A. G. 2016. Estimating the critical thermal maximum $532\left(\mathrm{CT}_{\max }\right.$ of bed bugs, Cimex lectularius: comparing thermolimit respirometry with traditional visual 533 methods. Comparative Biochemistry and Physiology Part A: Molecular \& Integrative Physiology, 534 197, 52-57.

535 Diffenbaugh, N. S., Krupke, C. H., White, M. A., \& Alexander, C. E. 2008. Global warming 536 presents new challenges for maize pest management. Environmental Research Letters, 3(4), 537044007.

Dylan, B. 2006. Metabolic rate variation in Glossina pallidipes (Diptera: Glossinidae): gender, 539 ageing and repeatability. Variability among individuals and populations: implications for 540 arthropod physiology, 40 
541 Desforges, J.-P., Marques, G. M., Beumer, L. T., Chimienti, M., Blake, J., Rowell, J. E., van

542 Beest, F. M. 2019. Quantification of the full lifecycle bioenergetics of a large mammal in the high

543 Arctic. Ecological Modelling, 401, 27-39

544 Gaitán-Espitia, J. D., Bacigalupe, L. D., Opitz, T., Lagos, N. A., Timmermann, T., \&

545 Lardies, M. A. 2014. Geographic variation in thermal physiological performance of the intertidal

546 crab Petrolisthes violaceus along a latitudinal gradient. Journal of Experimental Biology, jeb.

$547 \quad 108217$

548 Ghaedi, B., \& Andrew, N. R. 2016. The physiological consequences of varied heat exposure 549 events in adult Myzus persicae: a single prolonged exposure compared to repeated shorter 550 exposures. PeerJ, 4, e2290.

551 Greene, G., Leppla, N., \& Dickerson, W. 1976. Velvetbean caterpillar: a rearing procedure and 552 artificial medium. Journal of Economic Entomology, 69(4), 487-488.

553 Gregg, P. C., Del Socorro, A. P., Le Mottee, K., Tann, C. R., Fitt, G. P., \& Zalucki, M. P. 554 2019. Host plants and habitats of Helicoverpa punctigera and H. armigera (Hübner) (Lepidoptera:

555 Noctuidae) in inland Australia. Austral Entomology, 58(3), 547-560.

556 Gregg, P.C., Del Socorro, A.P., Le Mottee, K., Tann, C.R., Fitt, G.P., and Zalucki, M.P. 2018.

557 Host plants and habitats of Helicoverpa punctigera and H. armigera (Hübner) (Lepidoptera:

558 Noctuidae) in inland Australia. Austral Entomology.

559 Gregg, P. C., Henderson, G. S., Del Socorro, A. P., Le Mottee, K., \& Birchall, C. 2016.

560 Polyphagy in an uncertain environment: Helicoverpa punctigera in inland Australia. Austral

561 Ecology, 41(7), 819-828. doi:10.1111/aec.12374 
562 Gullan P. J. \& Cranston P. S. 2014. The Insects: An Outline of Entomology. Wiley Blackwell

563 Publishing, Chicester, UK.

564 Harris, R. M. B., Beaumont, L. J., Vance, T. R., Tozer, C. R., Remenyi, T. A., Perkins

565 Karasov, W. H., \& del Rio, C. M. 2007. Physiological ecology: how animals process energy,

566 nutrients, and toxins: Princeton University Press.

567 Kirkpatrick, S. E., Bowman, D. M. J. S. 2018. Biological responses to the press and pulse of

568 climate trends and extreme events. Nature Climate Change, 8(7), 579-587. doi:10.1038/s41558-

$569 \quad 018-0187-9$

570 Harrison, J. 2009. "Respiratory System," in Encyclopedia of Insects, ed. R.C. Vincent

571 Resh. 2 ed (Amsterdam: Elsevier), 1168.

572 Hazell, S. P., Neve, B. P., Groutides, C., Douglas, A. E., Blackburn, T. M., \& Bale, J. S. 2010.

573 Hyperthermic aphids: insights into behaviour and mortality. J Insect Physiol, 56(2), 123-131.

574 doi:10.1016/j.jinsphys.2009.08.022

575 Hodgson, C. 1991. Dispersal of Apterous aphids (Homoptera: Aphididae) from their host plant

576 and its significance. Bulletin of Entomological Research, 81(4), 417-427.

577 Heinrich, Bernd 1993. The hot-blooded insects: Strategies and mechanisms of thermoregulation,

578 Cambridge, Massachusetts: Harvard University Press, p. 601, ISBN 978-0-674-40838-8

579 Huang, J., \& Li, J. 2015. Effects of climate change on overwintering pupae of the cotton

580 bollworm, Helicoverpa armigera (Hübner) (Lepidoptera: Noctuidae). Int J Biometeorol, 59(7),

581 863-876. doi:10.1007/s00484-014-0903-8 
582 Hill, M. P., Bertelsmeier, C., Clusella-Trullas, S., Garnas, J., Robertson, M. P., \&

583 Terblanche, J. 2016. Predicted decrease in global climate suitability masks regional complexity

584 of invasive fruit fly species response to climate change. Biological Invasions, 18(4), 1105-1119.

585 IPCC. 2019. IPCC Special Report on Climate Change, Desertification, Land Degradation,

586 Sustainable Land Management, Food Security, and Greenhouse gas fluxes in Terrestrial

587 Ecosystems. Summary for Policymakers.

588 Kirkpatrick, T. 1961. Comparative morphological studies of Heliothis species (Lepidoptera:

589 Noctuidae) in Queensland. Queensland journal of agricultural science, 18(2).

590 Kolluru, G. R., Chappell, M. A., \& Zuk, M. 2004. Sex differences in metabolic rates in field 591 crickets and their dipteran parasitoids. Journal of Comparative Physiology B, 174(8), 641-648.

592 Kingsolver, J. G. 2009. The Well-Temperatured Biologist: (American Society of Naturalists

593 Presidential Address). The American Naturalist, 174(6), 755-768

594 Kingsolver, J. G., Arthur Woods, H., Buckley, L. B., Potter, K. A., MacLean, H. J., \&

595 Higgins, J. K. 2011. Complex life cycles and the responses of insects to climate change. In: Oxford 596 University Press.

597 Kellermann, V., van Heerwaarden, B., \& Sgrò, C. M. 2017. How important is thermal history?

598 Evidence for lasting effects of developmental temperature on upper thermal limits in Drosophila 599 melanogaster. Proceedings of the Royal Society B: Biological Sciences, 284(1855), 20170447.

600 Kingsolver, J. G., \& Umbanhowar, J. 2018. The analysis and interpretation of critical 601 temperatures. Journal of Experimental Biology, 221(12), jeb167858. 
602 Lutterschmidt, W.I., and Hutchison, V.H. 1997. The critical thermal maximum: 509 history and 603 critique. Canadian Journal of Zoology 75(10), 1561-1574.

604 Lighton, J. R., \& Turner, R. J. 2004. Thermolimit respirometry: an objective assessment of 605 critical thermal maxima in two sympatric desert harvester ants, Pogonomyrmex rugosus and P. 606 californicus. Journal of Experimental Biology, 207(11), 1903-1913.

607 Le Lann, C., Wardziak, T., Van Baaren, J., \& van Alphen, J. J. 2011. Thermal plasticity of 608 metabolic rates linked to life-history traits and foraging behaviour in a parasitic wasp. Functional 609 Ecology, 25(3), 641-651

610 Lignot, J., LeMaho, Y., \& McCue, M. 2012. Comparative Physiology of Fasting, Starvation, and 611 Food Limitation.

612 Li, C., Wang, L., Li, J., Gao, C., Luo, Y., \& Ren, L. 2019. Thermal survival limits of larvae 613 and adults of Sirex noctilio (Hymenoptera: Siricidae) in China. PLoS One, 14(6).

614 Marais, E., Klok, C. J., Terblanche, J. S., \& Chown, S. L. 2005. Insect gas exchange patterns: 615 a phylogenetic perspective. Journal of Experimental Biology, 208(23), 4495-4507.

616 Marais, E., Terblanche, J. S., \& Chown, S. L. 2009. Life stage-related differences in hardening 617 and acclimation of thermal tolerance traits in the kelp fly, Paractora dreuxi (Diptera, 618 Helcomyzidae). Journal of Insect Physiology, 55(4), 336-343.

619 Martínez, J. D., Cadena, C. D., \& Torres, M. 2016. Critical thermal limits of Poecilia caucana 620 (Steindachner, 1880) (Cyprinodontiformes: Poeciliidae). Neotropical Ichthyology, 14(1) 
621 McCue, M. D., Boardman, L., Clusella-Trullas, S., Kleynhans, E., \& Terblanche, J. S. 2016.

622 The speed and metabolic cost of digesting a blood meal depends on temperature in a major disease

623 vector. Journal of Experimental Biology, 219(12), 1893-1902.

624 Merkey, A. B., Wong, C. K., Hoshizaki, D. K., \& Gibbs, A. G. 2011. Energetics of 625 metamorphosis in Drosophila melanogaster. Journal of Insect Physiology, 57(10), 1437-1445.

626 Mironidis, G., \& Savopoulou-Soultani, M. 2008. Development, survivorship, and reproduction 627 of Helicoverpa armigera (Hübner) (Lepidoptera: Noctuidae) under constant and alternating 628 temperatures. Environmental Entomology, 37(1), 16-28.

629 Mironidis, G. K. 2014. Development, survivorship and reproduction of Helicoverpa armigera 630 (Hübner) (Lepidoptera: Noctuidae) under fluctuating temperatures. Bulletin of Entomological 631 Research, 104(6), 751-764.

632 Moyano, M., Candebat, C., Ruhbaum, Y., Álvarez-Fernández, S., Claireaux, G., 633 Zambonino-Infante, J.-L., \& Peck, M. A. 2017. Effects of warming rate, acclimation 634 temperature and ontogeny on the critical thermal maximum of temperate marine fish larvae. PLoS 635 One, 12(7), e0179928.

636 Montejo-Kovacevich, G., Martin, S. H., Meier, J. I., Bacquet, C. N., Monllor, M., Jiggins, C. 637 D., \& Nadeau, N. J. 2020. Microclimate buffering and thermal tolerance across elevations in a 638 tropical butterfly. Journal of Experimental Biology, 223(8).

639 Mundim, K. C., Baraldi, S., Machado, H. G., \& Vieira, F. M. 2020. Temperature coefficient 640 (Q10) and its applications in biological systems: Beyond the Arrhenius theory. Ecological 641 Modelling, 431, 109127. 
642 Nguyen, C., Bahar, M. H., Baker, G., \& Andrew, N. R. 2014. Thermal tolerance limits of 643 diamondback moth in ramping and plunging assays. PLoS One, 9(1), e87535.

644 Nyamukondiwa, C., \& Terblanche, J. S. 2010. Within-generation variation of critical thermal 645 limits in adult Mediterranean and Natal fruit flies Ceratitis capitata and Ceratitis rosa: thermal 646 history affects short-term responses to temperature. Physiological Entomology, 35(3), 255-264.

647 Nyamukondiwa, C., Weldon, C. W., Chown, S. L., le Roux, P. C., \& Terblanche, J. S. 2013. 648 Thermal biology, population fluctuations and implications of temperature extremes for the 649 management of two globally significant insect pests. Journal of Insect Physiology, 59(12), 11996501211.

651 O'Neill, K. M., Kemp, W. P., \& Johnson, K. A. 1990. Behavioural thermoregulation in three 652 species of robber flies (Diptera, Asilidae: Efferia). Animal Behaviour, 39(1), 181-191.

653 Oyen, K. J., Giri, S., \& Dillon, M. E. 2016. Altitudinal variation in bumblebee (Bombus) critical 654 thermal limits. Journal of thermal biology, 59, 52-57.

655 Qayyum, A., \& Zalucki, M. 1987. Effects of high temperature on survival of eggs of Heliothis 656 armigera (Hübner) and H. punctigera Wallengren (Lepidoptera: Noctuidae). Austral Entomology, 26(4), 295-298.

Quinlan, M. C., \& Gibbs, A. G. 2006. Discontinuous gas exchange in insects. Respiratory 659 physiology \& neurobiology, 154(1-2), 18-29.

660 Room, P. 1983. Calculations of temperature-driven development by Heliothis spp. (Lepidoptera:

661 Noctuidae) in the Namoi Valley, New South Wales. Journal of the Australian Entomological 662 Society, 22(3), 211-215. 
663 Secor, S. M. (2009). Specific dynamic action: a review of the postprandial metabolic response.

664 Journal of Comparative Physiology B, 179(1), 1-56.

665 Somero, G. 2010. The physiology of climate change: how potentials for acclimatization and 666 genetic adaptation will determine 'winners' and 'losers'. Journal of Experimental Biology, 213(6), $667912-920$.

668 Stevens, M. M., Jackson, S., Bester, S.A., Terblanche, J.S., \& Chown, S.L. 2010. Oxygen 669 limitation and thermal tolerance in two terrestrial arthropod species. Journal of Experimental 670 Biology (13), 2209-2218.

671 SAS Institute Inc., 2013. SAS/STAT 13.1 User's Guide. SAS Institute Inc., Cary, NC.

672 Sunday, J. M., Bates, A. E., Kearney, M. R., Colwell, R. K., Dulvy, N. K., Longino, J. T., \&

673 Huey, R. B. 2014. Thermal-safety margins and the necessity of thermoregulatory behavior

674 across latitude and elevation. Proceedings of the National Academy of Sciences, 201316145.

675 Shik, J. Z., Arnan, X., Oms, C. S., Cerdá, X., \& Boulay, R. 2019. Evidence for locally 676 adaptive metabolic rates among ant populations along an elevational gradient. Journal of animal 677 ecology, 88(8), 1240-1249

678 Shah, A. A., Woods, H. A., Havird, J. C., Encalada, A. C., Flecker, A. S., Funk, W. C., \& 679 Thomas, S. A. 2021. Temperature dependence of metabolic rate in tropical and temperate aquatic 680 insects: Support for the Climate Variability Hypothesis in mayflies but not stoneflies. Global 681 Change Biology, 27(2), 297-311.

682 Teakle, R. 1991. Laboratory culture of Heliothis species and identification of disease. In Heliothis:

683 research methods and prospects (pp. 22-29): Springer. 
684 Terblanche, J., Klok, C., \& Chown, S. 2004. Metabolic rate variation in Glossina pallidipes 685 (Diptera: Glossinidae): gender, ageing and repeatability. Journal of Insect Physiology, 50(5), 419686428.

687 Terblanche, J. S., \& Chown, S. L. 2007. The effects of temperature, body mass and feeding on 688 metabolic rate in the tsetse fly Glossina morsitans centralis. Physiological Entomology, 32(2), $689 \quad 175-180$.

690 Terblanche, J. S., Deere, J. A., Clusella-Trullas, S., Janion, C., \& Chown, S. L. 2007. Critical 691 thermal limits depend on methodological context. Proceedings of the Royal Society of London B: 692 Biological Sciences, 274 (1628), 2935-2943.

693 Terblanche, J.S., Clusella-Trullas, S., Chown, S.L. 2010. Phenotypic plasticity of gas exchange 694 pattern and water loss in Scarabaeus spretus (Coleoptera: Scarabaeidae): deconstructing the basis 695 for metabolic rate variation. Journal of Experimental Biology 213, 2940-2949.

696 Terblanche, J. S., Klok, C. J., \& Chown, S. L. 2005. Temperature-dependence of metabolic rate 697 in Glossina morsitans morsitans (Diptera, Glossinidae) does not vary with gender, age, feeding, 698 pregnancy or acclimation. Journal of Insect Physiology, 51(8), 861-870.

699 Terblanche, J. S., Sinclair, B. J., Klok, C. J., McFarlane, M. L., \& Chown, S. L. 2005. The 700 effects of acclimation on thermal tolerance, desiccation resistance and metabolic rate in Chirodica 701 chalcoptera (Coleoptera: Chrysomelidae). Journal of Insect Physiology, 51(9), 1013-1023.

702 Terblanche, J., Klok, C., \& Chown, S. 2004. Metabolic rate variation in Glossina pallidipes 703 (Diptera: Glossinidae): gender, ageing and repeatability. Journal of Insect Physiology, 50(5), 419704428. 
705 Thienel, M., Canals, M., Bozinovic, F., \& Veloso, C. 2015. The effects of temperature on the 706 gas exchange cycle in Agathemera crassa. Comparative Biochemistry and Physiology Part A:

707 Molecular \& Integrative Physiology, 183, 126-130.

708 The R Foundation for Statistical Computing Platform (C) 2018 (version 3.5.2.)

709 Tomlinson, S., \& Phillips, R. D. 2015. Differences in metabolic rate and evaporative water loss 710 associated with sexual dimorphism in thynnine wasps. Journal of Insect Physiology, 78, 62-68.

711 Vorhees, A. S., \& Bradley, T. J. 2012. Differences in critical thermal maxima and mortality

712 across life stages of the mealworm beetle Tenebrio molitor. Journal of Experimental Biology, 215 713 (13), 2319-2326.

714 Wang, T., Zaar, M., Arvedsen, S., Vedel-Smith, C., \& Overgaard, J. 2002. Effects of 715 temperature on the metabolic response to feeding in Python molurus. Comparative Biochemistry 716 and Physiology Part A: Molecular \& Integrative Physiology, 133(3), 519-527.

717 Whitman, D. W., \& Agrawal, A. A. 2009. What is phenotypic plasticity and why is it important.

718 Phenotypic plasticity of insects: Mechanisms and consequences, 1-63.

719 www.bom.gov.au/state-of-the-climate (2018).

720 White, C. R., Marshall, D. J., Alton, L. A., Arnold, P. A., Beaman, J. E., Bywater, C. L.,

721 Pirtle, E. 2019. The origin and maintenance of metabolic allometry in animals. Nature Ecology \& 722 Evolution, 3(4), 598-603.

723 Zalucki, M., Daglish, G., Firempong, S., \& Twine, P. 1986. The biology and ecology of 724 Heliothis-armigera (Hübner) and Heliothis-punctigera Wallengren (Lepidoptera: Noctuidae) in 725 Australia-What do we know. Australian Journal of Zoology, 34(6), 779-814. 
726 Zalucki, M. P., \& Furlong, M. J. 2005. Forecasting Helicoverpa populations in Australia: a

727 comparison of regression based models and a bioclimatic-based modelling approach. Insect

728 Science, 12(1), 45-56. 
Figure 1

Box plot showing the Total mean $\dot{\mathrm{V}} \mathrm{CO}_{2} \mathrm{ml} \mathrm{h}^{-1}$ among life stages (larvae, pupae and adult) of $\mathrm{H}$. punctigera over complete ramping period of about $120 \mathrm{mins}$ from $25^{\circ} \mathrm{C}$ to $55^{\circ} \mathrm{C}$ following thermolimit respirometry

The dark line is the median in each group 


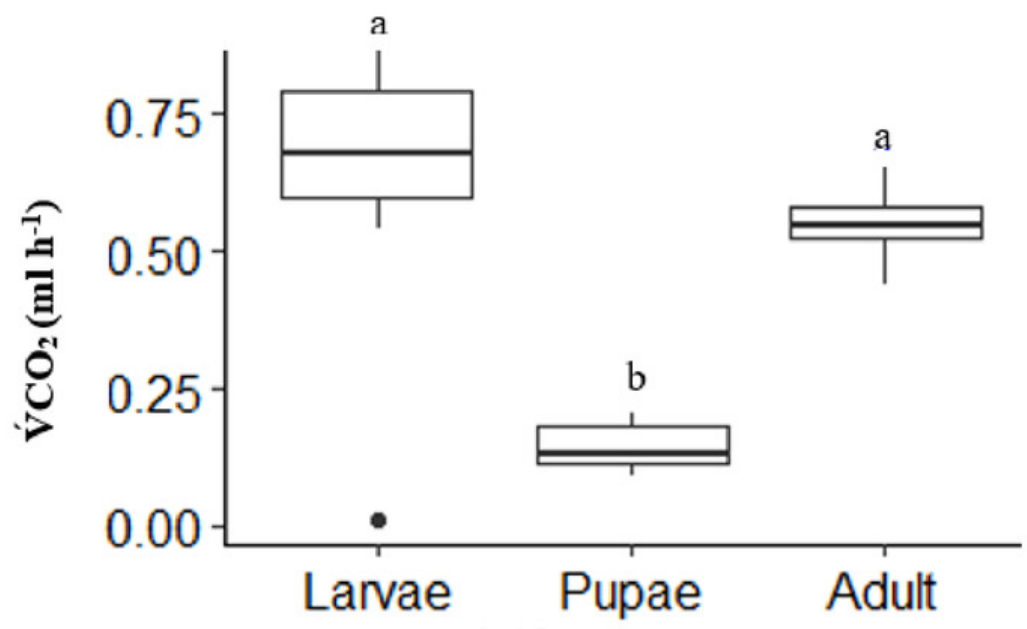

Life Stage

Figure 1: Metabolic rate $\mathrm{V} \mathrm{CO}_{2}\left(\mathrm{ml} \mathrm{h}^{-1}\right)$ boxplot of $H$. punctigera life stages (larvae, pupae and adult; $\mathrm{n}=10$ for all stages) over the complete ramping period of about $120 \mathrm{mins}$ from $25^{\circ} \mathrm{C}$ to $\mathrm{CT}_{\max }$ following thermolimit respirometry. Significant differences $(\mathrm{p}>0.05)$ indicated by the letter above each boxplot. The box represents the lower and upper quartiles with the dark line representing the mean. The bars represents the minimum and maximum whiskers, the dot represents an outlier. 
Figure 2

Box plot showing the Mean $\mathrm{CT}_{\max }$ identified as the inflection point in the absolute difference sum (ADS) residuals among life stages (larvae, pupae and adult) of $H$. punctigera following thermolimit respirometry.

The dark line is the median of the data in each group 


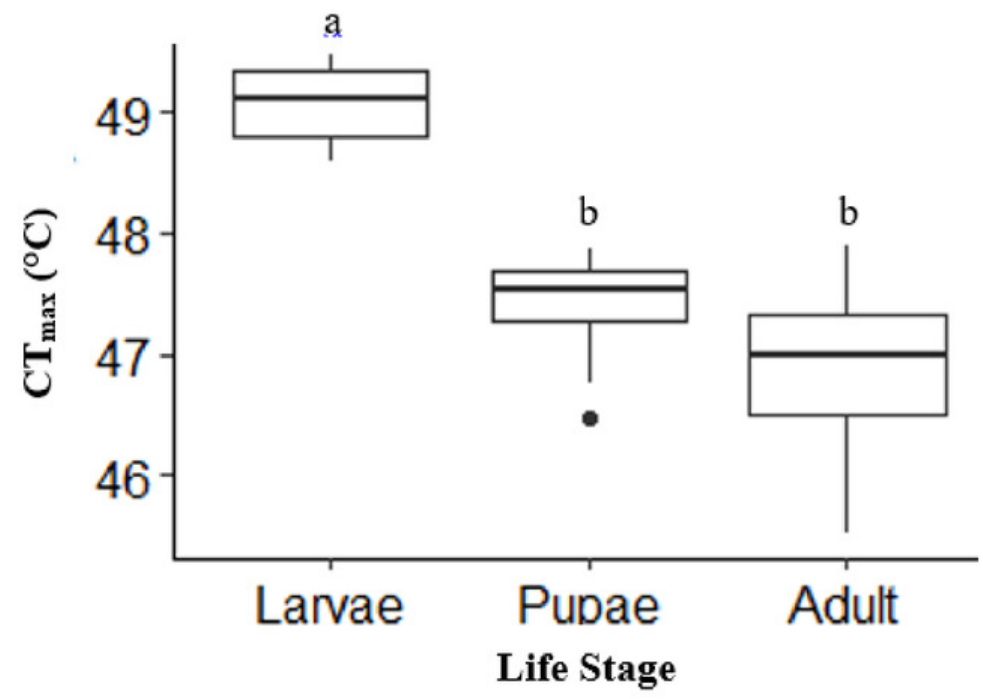

Figure 2: Upper thermal limit ( $\mathrm{CT}_{\max }$ ) identified as the inflection point in the absolute difference sum (ADS) residuals among life stages (larvae, pupae and adult; $\mathrm{n}=10$ for all stages) of $H$. punctigera following thermolimit respirometry. Box plots with the same letter are not significantly different $(\mathrm{p}>0.05)$. The box represents the lower and upper quartiles with the dark line representing the mean. The bars represents the minimum and maximum whiskers, the dot represents an outlier. 
Figure 3

Box plots comparisons of $H$. punctigera life stages (larvae, pupae and adult; $n=10$ for all stages) $\mathrm{Q}_{10}\left(25-35^{\circ} \mathrm{C}\right)$ and $\mathrm{Q}_{10}\left(35-45^{\circ} \mathrm{C}\right)$.

The box represents the lower and upper quartiles with the dark line representing the mean. The bars represents the minimum and maximum whiskers, the dots represent outliers. 

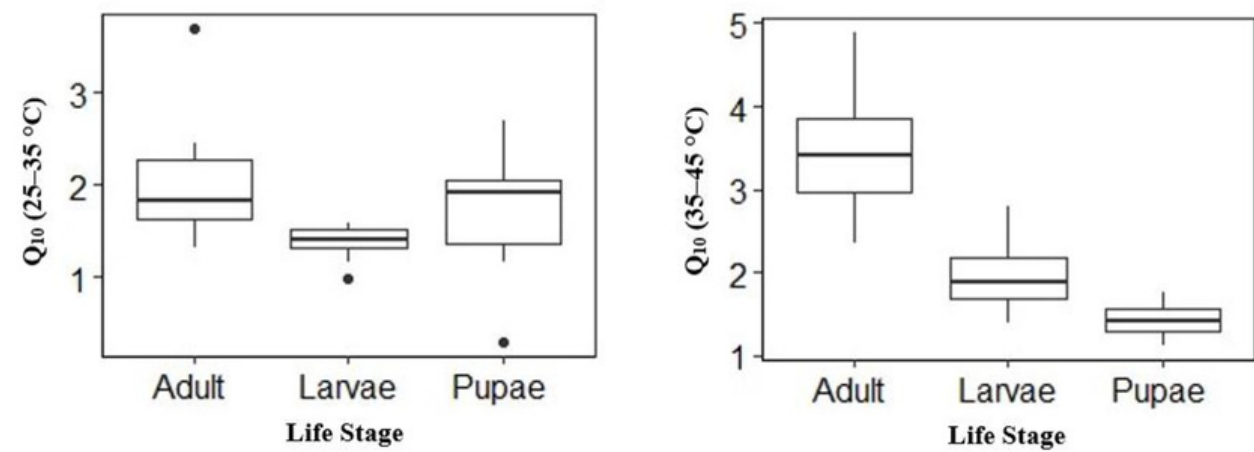

Figure 3: Box plots comparisons of $H$. punctigera life stages (adult, larvae and pupae; $\mathrm{n}=10$ for all stages) $\mathrm{Q}_{10}$ $\left(25-35^{\circ} \mathrm{C}\right)$ and $\mathrm{Q}_{10}\left(35-45^{\circ} \mathrm{C}\right)$. The box represents the lower and upper quartiles with the dark line representing the mean. The bars represents the minimum and maximum whiskers, the dots represent outliers. 


\section{Figure 4}

Box plots of upper thermal limit $\left(\mathrm{CT}_{\max }\right)$ identified as the inflection point in the absolute difference sum (ADS) residuals among Life Stage (pupae and adult) and sex (male - M and female $-F$ ) of $H$. punctigera following thermolimit respirom

The box represents the lower and upper quartiles with the dark line representing the mean. The bars represent the minimum and maximum whiskers, the dots represent outliers. 


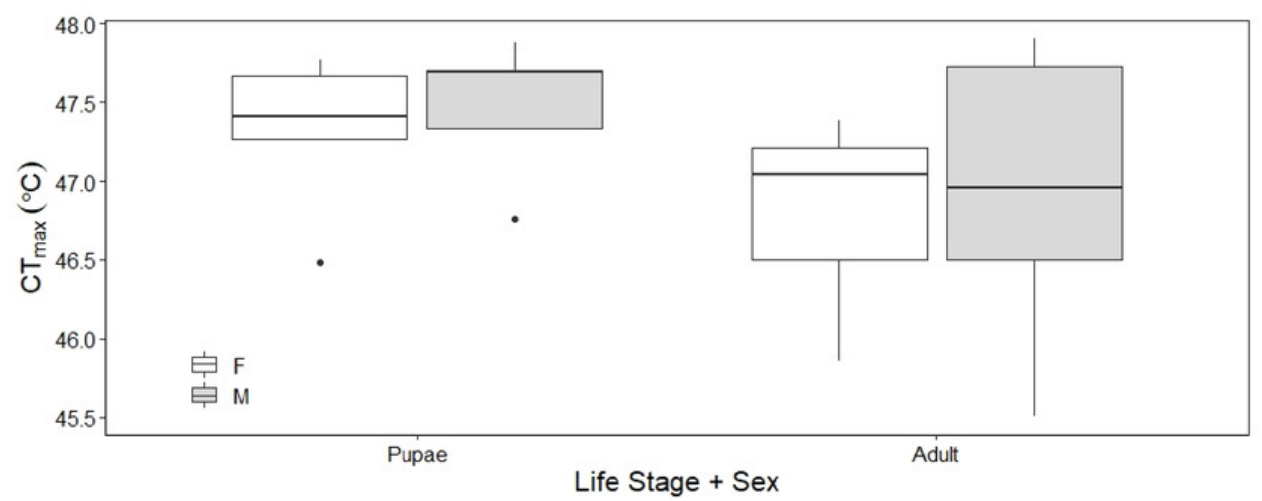

Figure 4: Box plots of upper thermal limit $\left(\mathrm{CT}_{\max }\right)$ identified as the inflection point in the absolute difference sum (ADS) residuals among Life Stage (pupae and adult) and sex (male $-\mathrm{M}$ and female $-\mathrm{F}$ ) of $H$. punctigera following thermolimit respirometry $; \mathrm{n}=5$ for all sexes. The box represents the lower and upper quartiles with the dark line representing the mean. The bars represent the minimum and maximum whiskers, the dots represent outliers. 
Figure 5

Box plots of $\mathrm{V́CO}_{2} \mathrm{ml} \mathrm{h}^{-1}$ among Life Stage (pupae and adult) and sex (male - $\mathrm{M}$ and female $-\mathrm{F}$ ) of $\mathrm{H}$. punctigera over the complete temperature ramping period of about 140 mins from $25^{\circ} \mathrm{C}$ to $\mathrm{CT}_{\max }$ following thermo

The box represents the lower and upper quartiles with the dark line representing the median. The bars represents the minimum and maximum whiskers, the dots represent outliers. 


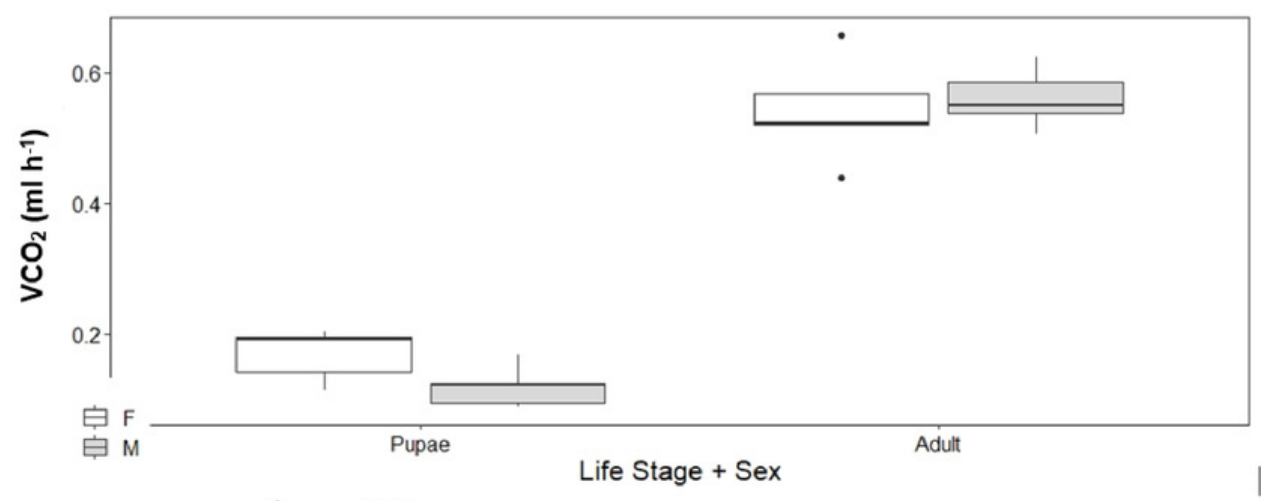

Figure 5: Box plots of $\mathrm{V}^{-} \mathrm{CO}_{2} \mathrm{ml} \mathrm{h}^{-1}$ among Life Stage (pupae and adult) and sex (male $-\mathrm{M}$ and female $-\mathrm{F}$ ) of H. punctigera over the complete temperature ramping period of about $140 \mathrm{mins}$ from $25^{\circ} \mathrm{C}$ to $\mathrm{CT}_{\max }$ following thermolimit respirometry. $\mathrm{n}=$ five in all cases; $\mathrm{n}=$ five for all sexes. The box represents the lower and upper quartiles with the dark line representing the median. The bars represents the minimum and maximum whiskers, the dots represent outliers. 


\section{Table $\mathbf{1}$ (on next page)}

Anova summary information for Activity $\mathrm{CT}_{\max }, \mathrm{CO}_{2} \mathrm{CT}_{\max }$ and mean $\mathrm{CT}_{\max }$ between two life stages (Larvae and Adults) of $H$. punctigera following thermolimit respirometry 
1

2 Table 1: Anova summary information for Activity $\mathrm{CT}_{\max }, \mathrm{CO}_{2} \mathrm{CT}_{\max }$ and mean $\mathrm{CT}_{\max }$ between two life stages (Larvae

3 and Adults) of $H$. punctigera following thermolimit respirometry. $\mathrm{n}=10$ for each life stage

\begin{tabular}{lcccccccc}
\hline & & & & & & & \multicolumn{2}{c}{ Mean $\mathrm{CT}_{\max }$} \\
\cline { 7 - 9 } Stage & DF & Sum Sq. & Mean Sq. & $\mathrm{F}$ & $\mathrm{p}$ & & Larvae & Adults \\
\hline Activity & 1 & 8.3 & 8.28 & 0.21 & 0.65 & & $44.1 \pm 1.3$ & $43.1 \pm 2.5$ \\
$\mathrm{CT}_{\max }$ & & & & & & & & \\
$\mathrm{CO}_{2} \mathrm{CT}_{\max }$ & 1 & 133.1 & 133.08 & 4.27 & 0.05 & & $49.0 \pm 0.3$ & $43.5 \pm 2.4$ \\
\hline
\end{tabular}




\section{Table 2 (on next page)}

Mean \pm s.e. $\mathrm{V}^{\prime} \mathrm{CO}_{2}\left(\mu \mathrm{l} \mathrm{CO}_{2} \mathrm{~h}^{-1}\right)$ over different temperature points among life stages (adult, larvae, and pupae).

Values in bold indicate significant differences. Letters indicate significant differences among

life stages. The $95 \% \mathrm{CL}$ is $95 \%$ confidence limit 
1 Table 2: Mean \pm s.e. $V^{\prime} \mathrm{CO}_{2}\left(\mu \mathrm{CO}_{2} \mathrm{~h}^{-1}\right)$ over different temperature points among life stages (adult, larvae, and pupae). Values in bold indicate significant differences.

2 Letters indicate significant differences among life stages. The $95 \% \mathrm{CL}$ is $95 \%$ confidence limit

\begin{tabular}{|c|c|c|c|c|c|c|c|c|c|c|c|c|}
\hline \multirow{2}{*}{$\begin{array}{l}\text { Life } \\
\text { Stage }\end{array}$} & \multicolumn{12}{|c|}{ Mean V́CO ${ }_{2}\left(\mu 1 \mathrm{CO}_{2} \mathrm{~h}^{-1}\right)$} \\
\hline & $25^{\circ} \mathrm{C}$ & $95 \% \mathrm{CL}$ & $30^{\circ} \mathrm{C}$ & $95 \% \mathrm{CL}$ & $35^{\circ} \mathrm{C}$ & $95 \% \mathrm{CL}$ & $40^{\circ} \mathrm{C}$ & $95 \% \mathrm{CL}$ & $45^{\circ} \mathrm{C}$ & $95 \% \mathrm{CL}$ & $\mathrm{CT}_{\max }$ & $95 \% \mathrm{CL}$ \\
\hline Larvae & $0.40 \pm 0.04 a$ & $0.31-0.50$ & $0.44 \pm 0.04 a$ & $0.43-0.62$ & $0.53 \pm 0.04 a$ & $0.57-0.76$ & $0.70 \pm 0.06 \mathrm{a}$ & $0.54-0.81$ & $1.03 \pm 0.22 a$ & $0.83-1.78$ & $1.03 \pm 0.14 a$ & $0.90-1.50$ \\
\hline Pupae & $0.08 \pm 0.03 b$ & $-0.03-0.11$ & $0.11 \pm 0.03 b$ & $0.02-0.15$ & $0.14 \pm 0.03 b$ & $0.08-0.22$ & $0.19 \pm 0.04 b$ & $-0.01-0.16$ & $0.24 \pm 0.16 b$ & $-0.09-0.60$ & $0.23 \pm 0.10 \mathrm{~b}$ & $-0.05-0.37$ \\
\hline Adult & $0.21 \pm 0.04 b$ & $0.16-0.36$ & $0.31 \pm 0.04 c$ & $0.21-0.41$ & $0.37 \pm 0.04 c$ & $0.22-0.43$ & $0.71 \pm 0.06 a$ & $0.71-1.01$ & $1.47 \pm 0.24 c$ & $0.91-1.92$ & $1.23 \pm 0.15 a$ & $1.01-1.65$ \\
\hline
\end{tabular}

3

4

5

6 
